\title{
Geology and time in renaissance
}

The 32nd session of the International Geological Congress (IGC) will be held in Florence, Italy, on August 20-28, 2004. It will be the second time for Italy to host the IGC, the first occasion having been the 2nd IGC session, held in Bologna in 1881. In the intervening 124 years, Italian geosciences have made great progress and have gained a leading position in many fields. Situated near the middle of the Mediterranean Sea, Florence will not only represent Italy at the IGC, but all the circumMediterranean countries and the Middle East. On behalf of Episodes, we sincerely wish the Congress every success.

In the present issue, Dr. Felix M. Gradstein and others, on behalf of the International Commission on Stratigraphy (ICS), summarize the new International Stratigraphic Chart and new numerical age calibration of the Geologic Time Scale. They provide a complete overview of the definition and current status of all standard stratigraphic stages and their boundaries. Special reference is made to the Precambrian part of the time scale, which is coming of age in terms of detail, and to the Neogene, which has attained an ultra-high-precision in its absolute-age calibration. The International Stratigraphic Chart is presented in two forms. One is in A4 format, placed within the text. The other is an A3 format insert, accompanying the issue, which will enable readers to put it on the wall of their office. Additional reprints of this article with its color insert will form part of the Congress registration package.

The reader may note that the Cenozoic Era of the new chart extends the Neogene System up to the present, without reference to the traditional Quaternary. For this, Dr. Jim Ogg has written a short note: "Introduction to concepts and proposed standardization of the term Quaternary"; and Dr. Brad Pillans, President of INQUA, offers a proposal on how to deal with the Qua- ternary in the time scale. These important and very positive contributions to global stratigraphy are included in the "Forum" section, as a supplement to the article of Gradstein et al., for open discussion.

The International Commission on the History of Geological Sciences (INHIGEO) has undertaken to organize a series of short articles for Episodes on the history of the different sessions of the International Geological Congress. These were held as follows: France (1878), Italy (1881), Germany (1885), UK (1888), USA (1891), Switzerland (1894), Russia (1897), France (1900), Austria (1903), Mexico (1906), Sweden (1910), Canada (1913), Belgium (1922), Spain (1926), South Africa (1929), USA (1933), USSR (1937), UK (1948), Algeria (1952), Mexico (1956), Denmark/Finland/Norway/Sweden/Iceland (1960), India (1964), Czechoslovakia (1968), Canada (1972), Australia (1976), France (1980), USSR (1984), USA (1989), Japan (1992), China (1996), Brazil (2000). The papers will not appear in chronological order. The first one was published in March this year. In this issue there is another paper entitled "Three sessions of the International Geological Congress held in Russia and the $\operatorname{USSR}(1897,1937,1984) "$. Any authors wishing to offer contributions on the meetings in Mexico (1906), Canada (1913), Belgium, Denmark, India, Canada (1972), and Brazil are invited to contact the INHIGEO Secretary-General at: <doldroyd@optushome.com.au>.

HOU, Hongfei
Managing Editor 
